\title{
A Probe Into Origins and Chinese Translation of English Allusions
}

\author{
LI Qi \\ School of Foreign Languages, Jinan University, Guangzhou City, China
}

\begin{abstract}
English Allusions are the unique and fixed expressions which mostly derive from the Western myths, legends, fables, literature and Western histories. They are crystallization of language and culture and closely related with cultural traditions. English Allusions have profound meaning although their forms are rather concise and terse. In daily communication, we always use allusions consciously or unconsciously. But the Chinese translation of English Allusions is a hard task for translators for their hidden and cultural background meaning is not as simple as their form. Therefore, this paper explores the origins and the corresponding translation of English allusions. It proposes three translation strategies in English allusion translation, aiming to help target readers accept the English allusions more easily and better understand Western culture through the use of English allusions.
\end{abstract}

Keywords: English allusions, origins, Chinese translation

\section{Introduction}

Allusions are of rich national characteristics and carry abundant cultural information. Undoubtedly, they reflect the essence of language and cultural knowledge. English has a myriad of allusions and the Chinese translation of English allusions has always been a hot topic in cross-cultural research. Successful Chinese translation of English allusions will not only enrich Chinese readers' language knowledge, but help them have a better understanding of Western culture. Therefore, this paper tries to explore origins and Chinese translation of English allusions. The whole paper is composed of three parts: the first part gives an overview of English allusions; the second part discusses five major origins of English allusions; and the third part proposes three translation strategies of English allusions.

\section{An Overview of English Allusion}

\section{Definition of English Allusion}

Allusions are brief and vivid expressions quoted from myths, fables, fairy tales, folk customs, religions, and literary works and featured with extensive implications and rich cultural connotations. Allusions have three main types: forms of words (e.g. Utopia, Muses, Prometheus); forms of phrases (Noun phrases: An apple of discord, Red herring, Wooden spoon; or Verb phrases: Spoil Egyptians, Carry coals to Newcastle, Face the music; or Prepositional phrases: Under the aegis of, To a T, From China to Peru); forms of sentences (It is Greek to me; Do in Roman as Romans do; Fish or cut the bait).

LI Qi, Master of Arts, School of Foreign Languages, Jinan University. 


\section{Functions of English Allusions}

Allusions are perfectly enchanting in our writing or speaking in that they can leave imaginary and thinking space for readers or hearers. Two main functions of allusions will be demonstrated here.

Make speech concise and vivid. Using English allusions properly in speech can make it more concise and vivid. We can express our affection, attitude and judgment in a roundabout way in concrete contexts. Sometimes allusions can back up our reasoning and make the truth sounder and clearer. Here is an example quoted from Hamlet by Shakespeare:

let menot think on't Frailty, thy name is woman!

In this sentence, we can notice the author's flexible application of English allusions. According to Old Testament of Bible, the first woman and mother of human race, Eve is fashioned by God from the rib of Adam. Therefore, the idea of "woman is fragile, subordinate to man" is rooted in Westerners' minds. This sentence is the reproach of Hamlet to his mother. Using the allusion here will associate people with the fragile quality of women, just like Hamlet's mother who is such a fragile woman that married to Hamlet's uncle the one usurped his father's throne only after one month of the death of Hamlet's father.

Make speech more acceptable and persuasive. Moreover, English allusions can also make the article more persuasive and greatly impress readers. Numerous examples about this function can be listed. Here is an example of English allusion also applied in advertisement of State Farm Insurance:

Like a good neighbor, State Farm is there (State Farm Insurance)

（州农场保险公司，亲如近邻。）

The allusion in the advertisement comes from New Testament of Bible_ "Love thy neighbor as thyself". This is an advertisement for propagating the thoughtful consideration of state farm insurance company. The allusion here expresses a conviction of serving customers at any time. Therefore, the application of the allusion has reached a good effect.

As it were, English allusions have permeated into every aspect of our life including economy, tourism, politics and more, and therefore exerted a great influence on our expressions and understanding. Using English allusions often makes our speech more acceptable and persuasive.

\section{Origins of English Allusions}

English Allusions have a variety of origins, but here the paper is going to introduce five major origins of them, namely, history event, literary works, Greek and Roman mythology, religion and fables.

\section{English Allusions From History Events}

History not only invents heroes but allusions. There are a number of examples to illustrate this point, such as Keep one's powder dry which comes from the Battle of Ireland led by Cromwell in 1649 and The Fifth Column which comes from Spanish Civil War in 1936.

Here is a typical example-To meet one's Waterloo. It is a very common and widely used allusion in our daily life; we often use it to express our sense of frustration and despair. Actually it originates from famous French general Napoleon, the founder of First French Empire. The Battle of Waterloo was fought near Waterloo (in present day Belgium) in 1815. The French army led by Emperor Napoleon was badly defeated by combined armies of the Seventh Coalition, an Anglo-Allied army led by the Duke of Wellington combined with a Prussian army led by Gebhard von Blücher. In the end, the defeat at Waterloo became the undoing of Napoleon, ending his rule as French Emperor. 


\section{English Allusions From Literary Works}

There is no denying that literary works has far-fetching and long-lasting influence on people's mind. For example, the allusion of "a pound of flesh" is from The Merchant of Venice by Shakespeare and it is used to express the meaning of a lawful, but ill-willed demand of payoff of a debt.

Uncle Tom's Cabin is the most powerful novel in American history and the second best-selling book of the 19th century (the first one is the Bible). The book's effect was so powerful that Lincoln said: "So this is the little lady who made this big war" when he met Stowe (the writer of Uncle Tom's Cabin). This novel invented an allusion of "Grow like Topsy". Topsy is a black slave girl who makes friends with Ophelia, the niece of slave owner. Here is a conversation in the book.

\footnotetext{
“Have you ever heard anything about God, Topsy?” The child looked bewildered, but grinned as usual. "Do you know who made you?"

"Nobody, as I knows on," said the child, with a short laugh. The idea appeared to amuse her considerably; for her eyes twinkled, and she added, “I spect I grow’d. Don’t think nobody never made me.” (Stowe, 1982, p. 172)
}

Topsy said she is growed rather than made to show her no-attention, no-care, no-love upbringing, she growed on her own. Since then, people use "grow like Topsy" to express the meaning of growing on one's own.

\section{English Allusions From Greek and Roman Mythology}

Greek and Roman Mythology is a collection of stories about Gods and legends of heroes. Greek and Roman Mythology can be seen in various ancient classic works of literature, history and philosophy, say Homer's Epic, witnessing the evolution of Western culture. The stories and legends in Greek and Roman Mythology are so abundant that many allusions out of Greek and Roman Mythology are widely spread around the world, such as Pandora's Box, The Web of Penelope, Helen of Troy. Swan song is a universally acknowledged and world-famous idiom. In the ancient Greek myth, swan is the divine bird of Apollo, who is the god of music. It is believed that swan sings only once in all his life, just in the article of death. And the song of swan is so melodic, melancholy and touching that people then use Swan song to express the meaning of the last masterpiece of poets, authors or composers.

\section{English Allusions From Religion}

It is beyond question that religion exerts great influence on Western culture. In English-speaking countries, Bible is undoubtedly the most influential classic in Christianity, the most prevailing and powerful religion. Therefore, Bible naturally becomes the rich sources of English allusions, such as Judas kiss, Noah's ark, Adam's apple. For example, Judas kiss, from the New Testament of Bible, refers to the hypocritical and deceptive behavior. Judas, one of the disciples of Jesus' twelve disciples, betrayed Jesus by identifying Jesus through his kiss on him. Consequently, Jesus got arrested and nailed on the cross. Later on, we use Judas kiss to express the meaning of unfaithful behavior.

\section{English Allusions From Fables}

Fables are another important origin of English allusions, which are short stories used to tell philosophy in life. There is no doubt that the most popular fable is Aesop. Aesop's fables create many classics, many of which have become allusions, such as Fish in troubled water; Since you sang all summer, you can dance all winter; Dance to somebody's pipe. 
For example, the allusion of Who is to bell the cat? originates from Aesop's fable The Mice in Council-this fable tells a story that a group of mice get bullied by a cat and one cunning mouse proposes to have a bell around the cat's neck so that the mice get alarmed when the cat approaches. Every mouse favors this suggestion until an old mouse asks: "who is to bell the cat?" Since then, people use Who is to bell the cat? to express the meaning that somebody will perform a very dangerous or very difficult task for the interests of everyone.

\section{Translation Strategies of English Allusions}

\section{Literal Translation}

Literal translation is a translation method which preserves language form of source language, conveys the exact meaning of source language and becomes acceptable by target language users. For example, $A$ wolf in sheep's clothing can be translated as 批着羊皮的狼 and All roads lead to Rome can be translated as 条条道 路通罗马.

Literal translation also includes transliteration, a translation method which converts words from one language to another language with a close approximation in phonetic sound. As the cultural exchange between China and the West getting more frequent, some important concepts or values in Western world can get accepted by target Chinese readers. In that case, transliteration will be an easy and economic method to translate allusions. For instance, Utopia can be translated as 乌托邦, and Marathon can be translated as 马拉松.

Readers' cognition and readers' cultural experience decide the application of literal translation. Readers are not passive recipients of information, for their cultural experience can gradually increase as a result of the cross culture communication, which will provide more possibility for literal translation method.

\section{Literal Translation With Explanation}

Literal translation with explanation is a translation method which maintains original form and meaning of source text and adds additional explanations of information. Literal translation can retain exotic cultural color as much as possible but not surely gets accepted by target readers, especially those allusions with rich cultural connotations. In that case, we can use literal translation with explanation strategy, supplementing hidden information behind the source language.

For example, “This is an apple of discord”. This sentence can be translated as “这是引起纠纷的苹果, 是 争执之源”. We present its hidden or root meaning by adding the information “是争执之源” (the root of dispute). An apple of discord in the Westerners' minds has a self-evident meaning, that is, the root of dispute. However, Chinese readers do not have. The easiest and economical way is to present its root meaning.

Literal translation with explanation not only retains the original style and features, but also presents its root meaning, so it is prone to be accepted by target readers. However, too tedious long explanations may become readers' burden, hence, explanations are required to be as succinct as possible.

\section{Find Close Equivalence in Target Language}

According to the translation principle of "Functional Equivalence", put forward by renowned translator Eugene Albert Nida, translation can hardly achieve complete equivalence due to the difference between language structures, cultures and religions. Nevertheless, translators could select from the source texts which is suitable for the communicative function of the target texts, that is to say, find close equivalence in target language. 
Here is an example-Sell One's Birthright for a Mess of Pottages refers to something of great, but deferred value for something of very low, but immediate value. According to the chapter 25 Genesis, Old Testament, Isaac, the Jewish patriarch had two sons, the elder named Esau, the younger named Jacob. One day, after Esau returned from hunting, hungry and thirsty, he noticed pottage made by his little brother. Jacob demanded Esau's birthright to exchange the pottage. Unexpectedly, Esau thought little of his birthright and swore to God to transfer his birthright to Jacob. Then Jacob gave Esau bread and pottage of lentiles; and he did eat and drink, and rose up, and went his way: thus Esau despised his birthright.

For Chinese readers, Bible is not one of the compulsory books to read. It is reasonable that Chinese readers know little about this idiom or allusion. If we translate it literally, it will be “为了一碗红豆汤而出卖了长子继 承权” and such literal translation means nothing to Chinese readers. In order to achieve communicative function, we can find its close equivalence in Chinese, translate it freely into 因小失大.

Another example, love me, love my dog. If it is literally translated into Chinese “爱我, 爱我的狗”, it will confuse Chinese people. In fact, the meaning of a Chinese idiom 爱屋及乌 is similar to the English allusion love me, love my dog. Therefore, we can turn to its close equivalence in Chinese to translate this allusion.

There are also many similar allusions we are familiar with—the salt of earth is translated into 社会中坚, cast pearls before swine is translated into 对牛弹琴, a drop in the bucket is translated into九牛一毛 and more.

\section{Conclusion}

In summary, English allusion is a window of English culture and the Chinese translation of English allusion can broaden Chinese readers' horizon and improve our knowledge about Western countries. However, the heavy culture-loaded information embedded in English allusions causes many difficulties in English-Chinese translation. The most difficult part of English allusion translation is that the root meaning is self-evident in the source language but needs to be explained by a lot of energy in the target language. Therefore, using literal translation with explanation and finding close equivalence in target language are good ways to present its rooted meaning of source language and literal translation especially can preserve the national characteristics of source language as much as possible.

\section{References}

King James Version. (2004). The Holy Bible. New York: Ivy Books.

Nida, E. A. (1993). Language, culture and translating. Shanghai: Shanghai Foreign Language Press.

Seidl, J., \& McMordie, W. (1988). English idioms and how to use them. Oxford: Oxford University Press.

Stowe, H. B. (1982). Uncle Tom's cabin. Gutenberg [Online]. Retrieved 13 January 2006 from http://www.gutenberg.org/ebooks/203 